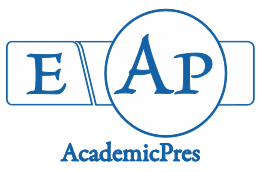

Taskin T et al. (2020)

Notulae Scientia Biologicae 12(2):222-232

DOI: $10.15835 / \mathrm{nsb} 12210687$

Research Article



\title{
In vitro anti-urease, antioxidant, anticholinesterase, cytotoxic and in vivo anti-inflammatory potential of Satureja cuneifolia Ten.
}

\author{
Turgut TAŞKIN ${ }^{1 *}$, Murat DOĞAN², Muhammet E. CAM ${ }^{1,3,4}$, \\ Talip ŞAHİN ${ }^{1}$, İsmail ŞENKARDEŞ ${ }^{1}$
}

\author{
${ }^{1}$ University of Marmara, Faculty of Pharmacy, 34668, Istanbul, Turkey; turguttaskin@marmara.edu.tr ( ${ }^{*}$ corresponding author); \\ muhammet.cam@marmara.edu.tr; talipsahin34@gmail.com;isenkardes@marmara.edu.tr \\ ${ }^{2}$ University of Sivas Cumburiyet, Faculty of Pharmacy, Sivas, Turkey; ecz.murat44@hotmail.com \\ ${ }^{3}$ Center for Nanotechnology and Biomaterials Application and Research (NBUAM) \\ ${ }^{4}$ University College London, Department of Mechanical Engineering, Torrington Place, London WCIE 7JE, UK
}

\begin{abstract}
Satureja cuneifolia Ten. (wild savoury) belongs to the Lamiaceae family and is used to produce essential oil and aromatic water. This plant is also used as a condiment and herbal tea due to its stimulating, tonic and carminative effects. The in vitro antioxidant, anti-urease, anticholinesterase and cytotoxic activities of the different extracts from the plant's aerial parts were examined. Besides, the in vivo anti-inflammatory activities of the fraction and direct methanol extracts were determined comparatively. In the current study, fraction methanol extract exhibited the strongest ABTS ( $52.34 \mathrm{mM}$ trolox $/ \mathrm{mg}$ extract) radical scavenging and ferric reduction (17.22 $\mathrm{mM} \mathrm{Fe} 2+/ \mathrm{mg}$ extract) activity. It was also found that the fraction methanol extract had stronger anti-urease (12.52\%) and anticholinesterase (69.02\%) activity than other extracts. The XTT results showed that fraction methanol extract had the most cytotoxic activity on MCF-7 cell lines (39.92\%). According to the results of in vivo anti-inflammatory activity, it was found that both fraction and direct methanol extracts exhibited close and significant anti-inflammatory activity. The fact that methanol extracts have significant biological activity suggests that these may be used as a natural source in the future.
\end{abstract}

Keywords: anti-urease; anticholinesterase; anti-inflammatory; cytotoxic; S. cuneifolia

\section{Introduction}

Satureja L. (Lamiaceae) is a genus aromatic plant and has 200 species that grow wild in the Middle East, Mediterranean region to Europe, West Asia, North Africa, the Canary Islands and South America. These species have their flavours and are generally consumed as medicinal tea and spices. The leaves, flowers, and stems of Satureja genus are used, in traditional medicine to treat various ailments, such as cramps, muscle pains, nausea, indigestion, diarrhoea, and infectious diseases. According to literature survey, Satureja species have been found to have antioxidant, antimicrobial, cytotoxic, acetylcholinesterase inhibitory, antiviral, antiinflammatory, herbicidal, hepatoprotective and antigenotoxic activities. Satureja cuneifolia Ten. (wild savoury) 
belongs to the Lamiaceae family and is used to produce essential oil and aromatic water. Also, this plant is used as a condiment and herbal tea due to its stimulating, tonic and carminative effects. In studies in Turkey, plant's essential oil has been found to include the major carvacrol and thymol compounds (Bezi et al., 2005; Oke et al., 2009; Tepe and Cilkiz, 2015; García-Rellána et al., 2016).

Alzheimer's is a neurodegenerative disease and is estimated to account for $50-60 \%$ of dementia cases in people over 65 years of age. Anticholinesterase drugs used for the treatment of dementia (for example, tacrin, donepezil, physostigmine, galantamine and heptilfizostigmin) are known to have various dangerous side effects such as hepatotoxicity, short biological effect time, low bioavailability, negative cholinergic side effects. Therefore, the number of studies on the cholinesterase activity of natural products has increased (Mogana $e t$ al., 2014; Butterfield and Halliwell, 2019; Henstridge et al., 2019; Long et al., 2019).

Oxidative stress plays a critical role in the pathogenesis and aging processes of various diseases such as cardiovascular, neurodegenerative, inflammatory diseases, cancer and diabetes. In recent years, natural antioxidants from medicinal plants have been extensively researched to find compounds that can protect against a range of diseases related to oxidative stress and free radical damage (Fang et al., 2002; Kindl et al., 2015; Ayoub et al., 2017; Ramos et al., 2020).

The primary physiological role of urease is to supply the organisms with nitrogen in the form of ammonia for their growth. The urease activity of Helicobacter pylori plays an important role in the pathogenesis of the stomach and peptic ulcer. Therefore, there has been a rapid increase in the number of studies on urease inhibitors in recent years (Hanif et al., 2012; Mimica-Dukic et al., 2018; Holleczek et al., 2019).

As far as we know, no data has been published about the in vitro anti-urease, cytotoxic and in vivo antiinflammatory effects of $S$. cuneifolia, and there is a lack of information about the anticholinesterase activity of this species. The study aims to reveal the in vitro (anti-urease, anticholinesterase, antioxidant, cytotoxic), in vivo (anti-inflammatory) biological effects of different extracts from $S$. cuneifolia.

\section{Materials and Methods}

\section{Identification of plant material}

Satureja cuneifolia Ten. was collected from the province of Balıkesir in Turkey during the flowering period and taxonomically identified by Dr. Ismail Senkardes. The voucher specimens, representative samples of the plant material, were archived in the Marmara University, Pharmacy Faculty herbarium and documented with the herbarium number of MARE: 18815.

\section{Preparation of Satureja cuneifolia extracts}

The aerial parts of $S$. cuneifolia were dried at $25^{\circ} \mathrm{C}$ in the shade. Dried parts of the plant $(50 \mathrm{~g})$ were extracted with organic solvents such as petroleum ether (SFPE), chloroform (SFC) and methanol (SFM) using the maceration method respectively until colourless. In addition, 20 grams of sample were extracted with direct methanol (SDM) solvent using the maceration method until the colourless. The different extracts from the plant were concentrated by a rotary vacuum evaporator.

\section{$D P P H$ radical scavenging assay}

$240 \mu \mathrm{L}$ DPPH solution $(0.1 \mathrm{mM})$ was added to $10 \mu \mathrm{L}$ sample of the extracts. The prepared mixture was stirred for $1 \mathrm{~min}$ and placed at $25^{\circ} \mathrm{C}$ for $30 \mathrm{~min}$. The mixture absorbance was determined against the reference at $517 \mathrm{~nm}$. The control sample was carried out under the same conditions using $10 \mu \mathrm{L}$ of methanol instead of experimental and standard materials and the control sample was daily measured. The investigation was performed three times. The data gained from the investigation was given as $\mathrm{IC}_{5_{0}}=\mathrm{mg} / \mathrm{mL}$ (Taskin, 2018). 


\section{ABTS $^{+}$scavenging assay}

$50 \mu \mathrm{L}$ of extracts, $50 \mu \mathrm{L}$ of ABTS ${ }^{+}$working solution and $150 \mu \mathrm{L}$ distilled water were added on the prepared extracts. The mixture absorbance was determined against the reference at $734 \mathrm{~nm}$ for $6 \mathrm{~min}$. The control sample was prepared under the same conditions with the use of $50 \mu \mathrm{L}$ distilled water instead of experimental and standard materials. The control sample was daily measured. ABTS radical scavenging determination was applied to trolox solutions prepared at different concentrations (0.2-1 mM). The results of this study were given as mM trolox/mg extract (Re et al., 1999).

\section{FRAP assay}

The method of Benzie and Strain (1996) was applied to the extracts to estimate the ferric reducing ability. The FRAP reagent was incubated for 30 minutes at $37^{\circ} \mathrm{C}$. Then, $190 \mu \mathrm{L}$ FRAP reagent was mixed with $10 \mu \mathrm{L}$ extract and the mixture absorbance was determined at $593 \mathrm{~nm}$ after $4 \mathrm{~min}$. FRAP values of the extracts were given as $\mathrm{mM} \mathrm{Fe} 2+/ \mathrm{mg}$ extract (Benzie et al., 1996).

\section{Anti-urease activity assay}

Stock solutions were prepared from different extracts obtained from the plant and these solutions were diluted to prepare working solutions. A working solution $(100 \mu \mathrm{L})$ was taken and urease $(500 \mu \mathrm{L})$ was added to it. The mixture was incubated at $37^{\circ} \mathrm{C}$ for $30 \mathrm{~min}$. Then, urea (1100) $\mu \mathrm{L}$ was added on this mixture and incubated at $37^{\circ} \mathrm{C}$ for $30 \mathrm{~min}$. R1 (1\% phenol, $0.005 \%$ sodium nitroprusside) and $\mathrm{R} 2(0.5 \% \mathrm{NaOH}, 0.1 \%$ sodium hypochlorite) reagents were added to the mixture, respectively. After the incubation period at $37^{\circ} \mathrm{C}$ for $2 \mathrm{~h}$, the absorbance of samples was measured at $635 \mathrm{~nm}$ (Taskin, 2018).

\section{Anticholinesterase activity assay}

Inhibition activities of acetylcholinesterase (AchE) were measured using a microplate reader. Acetylcholinesterase as an enzyme source derived from electric fish, acetyl thiokolin iodide was used as a substrate. Yellow-colored 5,5-dithiobis- (2-nitrobenzoic acid) (DTNB) was used for the measurement of activity. As a control, ethanol and galantamine, the alkaloid type drug isolated from the Galanthus plant, were used as controls.

AChE \% inhibition test: $\mathrm{AChE}(20 \mu \mathrm{L})$ and different concentrations of extracts $(20 \mu \mathrm{L})$ were added to phosphate buffer solution $(\mathrm{pH} 8.20 .1 \mathrm{M}, 40 \mu \mathrm{L})$. This mixture was incubated at $25^{\circ} \mathrm{C}$ for $10 \mathrm{~min}$. After incubation, DTNB $(100 \mu \mathrm{L})$ and $\mathrm{AcI}(20 \mu \mathrm{L})$ as substrate were added to the mixture. The same procedure was applied to the galantamine used as standard. 5-thio-2-nitrobenzoic acid was spectrophotometrically measured at $412 \mathrm{~nm}$. Anticholinesterase activity of the extracts was calculated using the following equation as\% inhibition relative to control (Ellman et al., 1961).

$$
\% \mathrm{I}=(\text { Acontrol }- \text { Asample/Acontrol }) \times 100
$$

\section{Total phenolic contents assay}

The total phenolic contents of the four different extracts from the plant were determined using the FCR method. Briefly, $0.1 \mathrm{~mL}$ extract $(5 \mathrm{mg} / \mathrm{mL}-0.5 \mathrm{mg} / \mathrm{mL})$ was taken in the tube and $4.5 \mathrm{~mL}$ of water was added. Then $0.1 \mathrm{~mL}$ of Folin-Ciocalteu reagent (diluted $1 / 3$ with distilled water) and $0.3 \mathrm{~mL}$ of $2 \%$ sodium carbonate solution were added to the mixture. The mixture was allowed to stand at room temperature for 2 hours, and then absorbance was measured at $760 \mathrm{~nm}$ against the reference. The total phenolic contents in the extracts were given as $\mathrm{mg}$ gallic acid equivalents/mg extract (Ozsoy et al., 2008). 


\section{In-vitro cytotoxicity assay}

This study was performed by modifying the study of Wolf et al. (2009). Cytotoxicity of Satureja cuneifolia extracts was measured by the XTT (2,3-bis-(2-methoxy-4-nitro-5-sulfophenyl)-2H-tetrazolium-5carboxanilide) cell viability assay, using MCF-7 and L-929 cell lines. Cell lines were cultured in low glucose DMEM containing $10 \% \mathrm{FBS}, 1 \% \mathrm{~L}$-glutamine, $100 \mathrm{IU} / \mathrm{mL}$ penicillin and $10 \mathrm{mg} / \mathrm{mL}$ streptomycin in $25 \mathrm{~cm}^{2}$ polystyrene flasks. The cells were kept at $37{ }^{\circ} \mathrm{C}$ within $5 \% \mathrm{CO}_{2}$ humidified atmosphere and were passaged when they had reached $85-90 \%$ confluence. Cells were seeded at $1 \times 104$ cells/well in 96-well plates with $100 \mu \mathrm{L}$ DMEM including 10\% FBS and incubated overnight. The extracts of $S$. cuneifolia, containing petroleum ether, chloroform, and methanol were dissolved in dimethyl sulfoxide (DMSO). These extracts with concentration $1 \mathrm{mg} / \mathrm{ml}$ were suspended with DMEM medium and extracts were put in the 96-well plates. Moreover, the same amount of DMSO was put in the positive control group. The cells were incubated for $24 \mathrm{~h}$. Then, the medium was removed and wells were washed with $200 \mu \mathrm{L}$ phosphate-buffered saline (PBS). Following these periods, for determination of living cells, $200 \mu \mathrm{L}$ DMEM and $50 \mu \mathrm{L}$ XTT labelling solution were added to each well and the plates were incubated for $4 \mathrm{~h}$. The absorbance values of XTT-formazan were measured using microplate (ELISA) reader at $450 \mathrm{~nm}$ against the control, as untreated cells. All experiments were performed three times and cell proliferation was expressed compared to control (100\% of viability).

\section{In vivo anti-inflammatory activity}

Carrageenan-induced paw edema was applied in female Sprague-Dawley rats (200-300 g) by sub-plantar injection of $0.1 \mathrm{ml}$ of $1 \%(\mathrm{w} / \mathrm{v})$ carrageenan in saline in the right hind paw. There are 4 groups, treated orally with saline $(10 \mathrm{ml} / \mathrm{kg}$ ), SFM (fraction methanol extract) $(200 \mathrm{mg} / \mathrm{kg}$ ), SDM (direct methanol extract) (200 $\mathrm{mg} / \mathrm{kg})$ and indomethacin $(5 \mathrm{mg} / \mathrm{kg}) 1 \mathrm{~h}$ before the administration of carrageenan. The volume of the edema development and its duration was determined for 4 hours using a plethysmometer. The study was approved by Marmara University, Animal Experiments Local Ethics Committee (MÜHDEK-58.2017.mar) (Vazquez et al., 2015; Taskin et al., 2019).

\section{Statistical analysis}

All the experiments were done in triplicates. The results of the antioxidant, anticholinesterase and antiurease experiments were demonstrated as mean \pm SD. All the data were analysed by the Graphpad Prism 5 program. Statistical differences between the study groups were analysed using two-way analysis of variance (ANOVA) followed by Tukey's multiple comparison test. The data obtained from the anti-inflammatory activity were analysed by PASW Statistics. The significance of the difference between means was determined by Mann Whitney $U$ test and p-values less than 0.05 were considered statistically significant.

\section{Results and Discussion}

\section{Antioxidant activity of extracts}

The antioxidant activities of plant's different extracts were shown in Table 1. The fraction chloroform $\left(\mathrm{IC}_{50}: 0.03 \mathrm{mg} / \mathrm{mL}\right)$ and direct methanol $\left(\mathrm{IC}_{50}: 0.07 \mathrm{mg} / \mathrm{mL}\right)$ extracts exhibited stronger DPPH free radical scavenging activity than other extracts. It was also found that fraction petroleum ether extract had the lowest DPPH radical scavenging activity. In this study, the free radical scavenging activities of the plant' different extracts were found to be lower compared to the standards ascorbic acid $\left(\mathrm{IC}_{50}: 0.006 \mathrm{mg} / \mathrm{mL}\right.$ ) and BHT (IC $\mathrm{I}_{50}$ : $0.009 \mathrm{mg} / \mathrm{mL}$ ) used. In the ABTS experiment, it was determined that all the extracts from the plant showed close ABTS radical scavenging activity. When the TEAC values of all extracts were compared, it was found that the fraction methanol $(52.34 \mathrm{mM}$ trolox $/ \mathrm{mg}$ extract) extract had the highest TEAC value and also showed activity close to the BHA compound $(52.63 \mathrm{mM}$ trolox/mg) as standard. In the FRAP experiment, direct 
methanol (17.08 $\mathrm{mM} \mathrm{Fe} / \mathrm{mg}$ extract), fraction chloroform $\left(17.15 \mathrm{mM} \mathrm{Fe} e^{2+} / \mathrm{mg}\right.$ extract) and fraction methanol (17.22 $\mathrm{mM} \mathrm{Fe}^{2+} / \mathrm{mg}$ extract) extracts were found to have close ferric reduction activity and were also found to have stronger ferric reduction activity than the BHT $\left(14.12 \mathrm{mM} \mathrm{Fe}{ }^{2+} / \mathrm{mg}\right)$ and BHA $(16.91 \mathrm{mM}$ $\left.\mathrm{Fe}^{2+} / \mathrm{mg}\right)$.

Phenolic compounds contained in plant extracts were determined by FCR method and according to the data obtained, it was determined that direct methanol $(0.071 \mathrm{mg} \mathrm{GAE} / \mathrm{mg}$ extract) and fraction methanol ( $0.074 \mathrm{mg} \mathrm{GAE} / \mathrm{mg}$ extract) extracts contained close phenolic contents. In this study, when the relationship between phenolic contents amount and antioxidant activities were evaluated, a linear relationship was found between the amount of phenolic contents contained in the fraction methanol extract and ABTS and FRAP activities.

Table 1. The antioxidant activity and total phenolic contents of the plant's different extracts

\begin{tabular}{|c|c|c|c|c|}
\hline Samples & $\begin{array}{c}\text { DPPH } \\
\left(\mathrm{IC}_{50} \mathrm{mg} / \mathrm{mL}\right)\end{array}$ & $\begin{array}{c}\text { ABTS }(\mathrm{mM} \text { trolox } / \mathrm{mg} \\
\text { extract })\end{array}$ & $\begin{array}{c}\text { FRAP assay }(\mathrm{mM} \\
\left.\mathrm{Fe}^{2+} / \mathrm{mg} \text { extract }\right)\end{array}$ & $\begin{array}{c}\text { Total phenolic } \\
(\mathrm{mgGAE} / \mathrm{mg} \text { extract })\end{array}$ \\
\hline SFPE & $0.27 \pm 0.01^{\mathrm{a}}$ & $51.08 \pm 0.016^{\mathrm{a}}$ & $9.31 \pm 0.04^{\mathrm{a}}$ & $0.043 \pm 0.001^{\mathrm{a}}$ \\
\hline SFC & $0.03 \pm 0.004^{\mathrm{b}}$ & $52.14 \pm 0.008^{\mathrm{b}}$ & $17.15 \pm 0.007^{\mathrm{b}}$ & $0.062 \pm 0.009^{\mathrm{b}}$ \\
\hline SFM & $0.07 \pm 0.0007^{\mathrm{c}}$ & $52.34 \pm 0.016^{\mathrm{cb}}$ & $17.22 \pm 0.009^{\mathrm{c} b \mathrm{~b}}$ & $0.074 \pm 0.002^{\mathrm{c}}$ \\
\hline SDM & $0.04 \pm 0.006^{\mathrm{d}}$ & $51.37 \pm 0.016^{\mathrm{d}}$ & $17.08 \pm 0.011^{\mathrm{d}}$ & $0.071 \pm 0.005^{\mathrm{d}}$ \\
\hline Ascorbic acid & $0.006 \pm 0.01^{\mathrm{e}}$ & & & \\
\hline BHT & $0.009 \pm 0.001^{\mathrm{f}}$ & & $14.12 \pm 0.07^{\mathrm{e}}$ & \\
\hline BHA & & $52.63 \pm 0.009^{\mathrm{e}}$ & $16.91 \pm 0.02^{\mathrm{f}}$ & \\
\hline
\end{tabular}

Values are mean of triplicate determination $(\mathrm{n}=3) \pm$ standard deviation; Means with different superscripts ${ }^{(\mathrm{a} e)}$ are significantly different, $p<0.05$; SFPE: fraction petroleum ether extract, SFC: fraction chloroform extract, SFM: fraction methanol extract, SDM: direct methanol extract, BHT: Butylated hydroxytoluene, BHA: Butylated hydroxyanisole, GAE: gallic acid equivalent

\section{Urease and acetylcholinesterase inhibitory activity}

The results of anti-urease and anticholinesterase activity of different extracts are shown in Table 2 . The fraction methanol (12.52\%) and direct methanol (9.65\%) extracts exhibited stronger anti-urease activity than other extracts. When the enzyme inhibitor activities of the extracts and standard compound were compared, it was determined that all extracts showed a lower percentage of enzyme inhibition than thiourea $(70.05 \%)$ compound. In anticholinesterase assay, the acetylcholinesterase enzyme inhibition activities of the different extracts at a concentration of $500 \mu \mathrm{g} / \mathrm{mL}$ were examined and it was determined that the fraction methanol (69.02\%) and direct methanol (48.96\%) extracts showed the highest enzyme inhibition. According to this study, all the extracts had lower anticholinesterase activity than galantamine (94.52\%).

Table 2. The enzyme inhibitory activity of different parts from S. cuneifolia

\begin{tabular}{|c|c|c|}
\hline Samples & $\begin{array}{c}\text { Urease inhibition }(\%) \\
(12.5 \mu \mathrm{g} / \mathrm{mL})\end{array}$ & $\begin{array}{c}\text { Acetylcholinesterase inhibition } \\
(\%)(500 \mu \mathrm{g} / \mathrm{mL})\end{array}$ \\
\hline SFPE & $6.20 \pm 0.77^{\mathrm{a}}$ & $15.24 \pm 1.08^{\mathrm{a}}$ \\
\hline SFC & $3.98 \pm 0.05^{\mathrm{b}}$ & $35.46 \pm 2.04^{\mathrm{b}}$ \\
\hline SFM & $12.52 \pm 0.66^{\mathrm{c}}$ & $69.02 \pm 0.39^{\mathrm{c}}$ \\
\hline SDM & $9.65 \pm 0.45^{\mathrm{d}}$ & $48.96 \pm 0.49^{\mathrm{d}}$ \\
\hline Thiourea & $70.05 \pm 0.75^{\mathrm{e}}$ & $94.52 \pm 0.14^{\mathrm{e}}$ \\
\hline Galantamine & & \\
\hline
\end{tabular}

Values are mean of triplicate determination $(\mathrm{n}=3) \pm$ standard deviation; Means with different superscripts ${ }^{(a-e)}$ are significantly different, $p<0.05$; SFPE: fraction petroleum ether extract, SFC: fraction chloroform extract, SFM: fraction methanol extract, SDM: direct methanol extract 


\section{Cytotoxicity result of extract}

The cytotoxic activities of S. cuneifolia extracts on MCF-7 and L 929 cell lines were examined and the rate of cell death is presented in Figure 1. The results showed that methanol extracts of the plant had the most cytotoxic activity on both MCF-7 and L-929 cell lines. Cell death rates of extracts on MCF-7 cell line were $28.29 \pm 1.34 \%$ (petroleum ether), $32.73 \pm 1.67 \%$ (chloroform), 39.92 $\pm 1.82 \%$ (methanol). Moreover, cell death rates of extracts on L-929 cell line were $22.95 \pm 2.31 \%$ (petroleum ether), $27.07 \pm 2.40 \%$ (chloroform), $27.61 \pm 1.44 \%$ (methanol) respectively. Cell viability below $70 \%$ is considered to be a cytotoxic effect (Wolf $e t$ al., 2000). The XTT results showed that the extracts of S. cuneifolia were not cytotoxic on the L-929 cell line. However, the extracts of the plant were cytotoxic effect on the MCF-7 cell line. The extracts of plant were cytotoxic on MCF-7 cell line, but were not cytotoxic on L-929 cell line is a promising and crucial result.
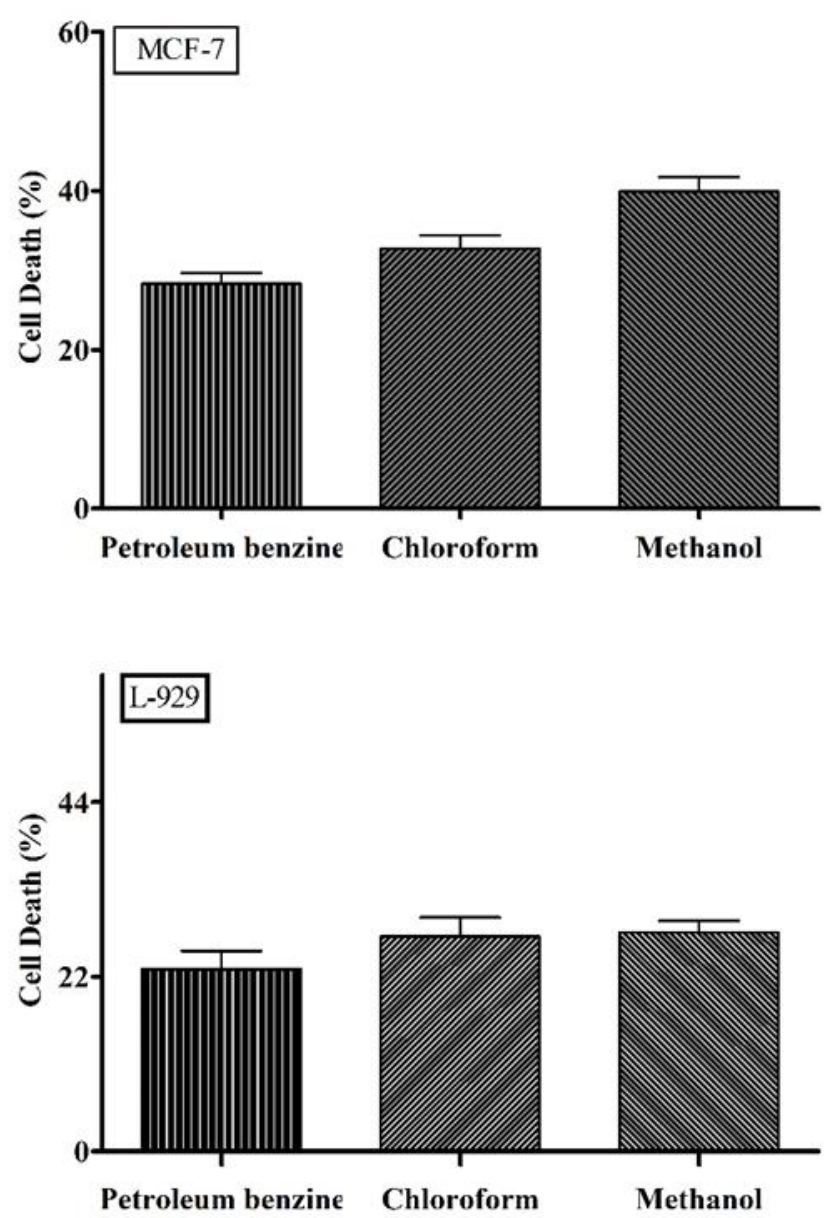

Figure 1. Cell death rate of MCF-7 and L-929 after the treatment of extracts of $S$. cuneifolia. The cell proliferation of extracts was expressed compared to control ( $100 \%$ of viability)

\section{In vivo evaluation of the anti-inflammatory activity}

The injection of carrageenan showed a significant increase in the volume of paw, reaching its maximum of $4 \mathrm{~h}$ post-injection (Taskin et al., 2019). Indomethacin $(5 \mathrm{mg} / \mathrm{kg}$ ) indicated maximum anti-inflammatory effect 4 hours after carrageenan injection by $56,8 \%$ (Table 3, p <0.001). SDM demonstrated a more prominent and intensive anti-inflammatory effect at first hour with $65.9 \%$ of inhibitive capacity in the altered edema size. However, SDM lost its anti-inflammatory effect rapidly in 4 hours. On the other hand, SFM protected its antiinflammatory effect in 4 hours (\%27.1, $\mathrm{p}<0.01$ ) compared to the control group (Figure 2). 
Table 3. Effects of SFM and SDM on carrageenan-induced paw edema in rats

\begin{tabular}{|c|c|c|c|c|}
\hline Treatment & $0 \mathrm{~h}$ & $1 \mathrm{~h}$ & $2 \mathrm{~h}$ & $4 \mathrm{~h}$ \\
\hline Control & $1.17 \pm 0.05$ & $1.61 \pm 0.07$ & $1.83 \pm 0.10$ & $2.35 \pm 0.14$ \\
\hline SFM & $1.10 \pm 0.04$ & $1.29 \pm 0.02^{*}$ & $1.52 \pm 0.05^{*}$ & $1.96 \pm 0.05^{* *++}$ \\
\hline SDM & $1.15 \pm 0.03$ & $1.30 \pm 0.05^{*}$ & $1.56 \pm 0.07^{+}$ & $2.21 \pm 0.07^{+++}$ \\
\hline indomethacin & $1.05 \pm 0.04$ & $1.21 \pm 0.06^{* *}$ & $1.27 \pm 0.06^{* * *}$ & $1.56 \pm 0.08^{* * *}$ \\
\hline
\end{tabular}

Values are expressed as Mean \pm SEM (Standard error mean); Values are calculated using two-way ANOVA followed by Bonferroni posttests; ${ }^{*} \mathrm{p}<0.05,{ }^{* *} \mathrm{p}<0.01,{ }^{* * *} \mathrm{p}<0.001$ vs. control; ${ }^{+} \mathrm{p}<0.05,{ }^{++} \mathrm{p}<0.01,{ }^{+++} \mathrm{p}<0.001$ vs. indomethacin.



Figure 2. Values are expressed in volume of paw before carrageenan injection and mean \pm SEM (Standard error mean) from 6 animals in the treatment group, ${ }^{*} \mathrm{p}<0.05,{ }^{* *} \mathrm{p}<0.01$, ${ }^{* * *} \mathrm{p}<0.001$ vs. control; ${ }^{+} \mathrm{p}<$ $0.05,{ }^{++} \mathrm{p}<0.01,{ }^{+++} \mathrm{p}<0.001$ vs. indomethacin

The chemical composition of the essential oil from the plant's aerial parts was analysed by the GC-MS method, and the antioxidant activities of the essential oil and methanol extracts which is prepared using the Soxhlet method were examined. It was found that carvacrol and $p$-cymene compounds were found to be major in essential oil. It has been determined that methanol extract has stronger DPPH radical scavenging ( IC $_{50} 26.0$ $\mu \mathrm{g} / \mathrm{mL}$ ) and $\beta$-carotene bleaching $(95.2 \%)$ activity than essential oil $\left(\mathrm{IC}_{50} 65.1 \mu \mathrm{g} / \mathrm{mL}, 84.5 \%\right)$ (Oke et al., 2009).

In our study, when $\mathrm{IC}_{50}$ values of direct methanol $\left(\mathrm{IC}_{50} 40 \mu \mathrm{g} / \mathrm{mL}\right)$ extract from aerial parts of plant were compared with the study above, the DPPH radical scavenging activity obtained in this study was found to be lower than the DPPH radical scavenging activity above $\left(\mathrm{IC}_{50} 26.0 \mu \mathrm{g} / \mathrm{mL}\right)$. In other studies, $\beta$-cubebene, camphor, camphene, spathulenol, and $\beta$-caryophyllene were found as major compounds in essential oil from aerial parts of plant. Also, it has been found that essential oils showed strong antimicrobial activity against Staphylococcus aureus, Escherichia coli, Candida albicans, Saccharomyces cerevisiae, Amaranthus hybridus and Conyza canadensis (Bezi et al., 2005; García-Rellána et al., 2016). In the last study, the antioxidant, antiAlzheimer, antidiabetic activities of methanol and water extracts from the aerial parts of the plant was examined and the phenolic contents was analysed by LC-MS/MS (Taslimi et al., 2020). The methanol extract was found to show stronger anti-Alzheimer (AChE: $\left.\mathrm{IC}_{50} 63.69 \mu \mathrm{g} / \mathrm{mL} ; \mathrm{BChE}^{\mathrm{IC}} \mathrm{IC}_{50} 23.17 \mu \mathrm{g} / \mathrm{mL}\right)$ and antidiabetic $(\alpha-$ 
glycosidase: $\mathrm{IC}_{50} 10.66 \mu \mathrm{g} / \mathrm{mL}$ ) activity than water extract. It has also been determined that this extract has stronger DPPH (IC50 $26.03 \mu \mathrm{g} / \mathrm{mL}$ ), FRAP ( $\lambda 700$ 1.344), CUPRAC ( $\lambda 4501.203)$ and ABTS (IC50 14.98 $\mu \mathrm{g} / \mathrm{mL}$ ) radical scavenging activity than water extract. It was determined that rutin, kaempferol-3-O-rutinoside and fumaric acid compounds were the most common in the plant.

In our study, it was determined that direct methanol extract $\left(\mathrm{IC}_{50} 40 \mu \mathrm{g} / \mathrm{mL}\right)$ showed lower DPPH radical scavenging activity than the above study $\left(\mathrm{IC}_{50} 26.03 \mu \mathrm{g} / \mathrm{mL}\right)$ as well as in parallel with this study, it was found that it showed significant activity in ABTS, FRAP and CUPRAC methods. Also, in this study, the activity of both fraction and direct methanol extracts on cholinesterase enzyme was examined, and it was found that the fraction methanol extract (69.02\%) showed stronger inhibition than direct methanol extract (48.96\%).

The anti-inflammatory and analgesic activities of essential oil, hydroalcoholic and polyphenolic extracts of the seeds of the Satureja hortensis were examined with acetic acid and formalin (analgesic methods) and carrageenan-induced rat paw edema (anti-inflammatory) tests. In this study, it was found that these extracts decreased acetic acid-induced abdominal twitches and paw edema (Hajhashemi et al., 2012; Jafari et al., 2016). Antinociceptive and anti-inflammatory activity of hydroalcoholic extract of $S$. khuzestanica was evaluated using formalin and carrageenan-induced rat paw edema test. In this study, the hydroalcoholic extract of plant $[150 \mathrm{mg} / \mathrm{kg}$; intraperitoneally (i.p.) $]$ has been found to have as effective anti-inflammatory activity as indomethacin ( $4 \mathrm{mg} \mathrm{kg}$; i.p.). Besides, the hydroalcoholic extract was found to show significant antinociceptive activity compared to morphine (Amanlou et al., 2005. In our study, it was found that methanol extracts of the plant in parallel with the above literature data showed significant anti-inflammatory activity compared to the control.

The cytotoxic activity of $S$. intermedia essential oil was evaluated by MTT method on human cancerous cells (esophageal squamous cell carcinoma and human bladder carcinoma cell lines). The results revealed that essential oil showed considerable activity ranging from $39 \mu \mathrm{g} / \mathrm{mL}$ to $1,000 \mu \mathrm{g} / \mathrm{mL}$ (IC I $_{0} 156 \mu \mathrm{g} / \mathrm{mL}$ ) (Sadeghi et al., 2013). The cytotoxic activities of $S$. sahendica essential oil against MCF-7, Vero, SW 480 and JET 3 cell lines was examined by MTT method and it was observed that the essential oil showed strong cytotoxic activity on MCF-7 (IC $5015.6 \mu \mathrm{g} / \mathrm{mL}$ ), Vero (IC $5015.6 \mu \mathrm{g} / \mathrm{mL}$ ), SW480 (IC $50125 \mu \mathrm{g} / \mathrm{mL})$, and JET 3(IC $50250 \mu \mathrm{g} / \mathrm{mL}$ ) cell lines (Yousefzadi et al., 2012). The cytotoxic activity of the methanol extract of $S$. kitaibelii was examined and it was found that methanol extract exhibited strong cytotoxic activity against Fem-X Human Malignant Melanoma cells (IC50 $39.66 \mu \mathrm{g} / \mathrm{mL})$ and moderate activity against MDA-MB-361 ((IC $50361 \mu \mathrm{g} / \mathrm{mL})$ and HeLa ((IC $50173 \mu \mathrm{g} / \mathrm{mL})$ cell lines. Satureja odora and S. parvifolia dichloromethane extracts were tested for toxicity on brine shrimp, and these extracts were a promising activity was observed ( $\mathrm{LC}_{50}$ value $<200 \mu \mathrm{g} / \mathrm{mL}$ ). As seen in the studies presented here, it has been determined that the extracts and essential oils of the Satureja species show cytotoxic activity. Besides, phytochemical compounds (rosmarinic acid, 5,7,3',5'-tetrahydroxy flavanone, 5,4'-dihydroxy-3'-methoxyflavanone-7-(6"-O- $\alpha$-L-rhamnopyranosyl)- $\beta$-D glucopyranoside) of plants are known to have important cytotoxic activities (Tepe and Cilkiz, 2015). In our study, it was observed that the plant's methanol extract showed promising cytotoxic activity in cancer cell line (MCF-7) similar to the above data.

Inhibitory activities of essential oil or extracts (water, ethanol) of S. khuzestanica, S. montana, $S$. parvifolia, and $S$. thymbra were evaluated for their AChE and BChE. According to these study, essential oil or extracts of plants had a promising enzyme inhibition activity. According to literature reviews, $S$. hortensis, $S$. khuzestanica and $S$. montana, in general, exhibited strong antioxidant activity due to their oxygenated monoterpenes (especially, carvacrol and thymol contents) and polar phytochemicals (Tepe and Cilkiz, 2015). In our study, as in previous studies, it was determined that the plant's methanol extracts has strong antioxidant and anticholinesterase activity.

Satureja species are known to contain essential oils, phenolic acids (gallic acid, vanillic acid, caffeic acid, chlorogenic acid), flavonoids (luteolin, apigenin, cirsilineol, acacetin), and these compounds have various 
biological activities (antioxidant, anticholinesterase, antispasmodic, anti-inflammatory etc.) (Tepe and Cilkiz, 2015). In the previous study by Taslimi et al., phenolic acid (gallic acid, fumaric acid, ellagic acid) and flavonoid compounds (apigenin, luteolin, rutin) in the methanol extract of Satureja cuneifolia were analysed by LCMS/MS technical (Taslimi et al., 2020). In this study, Satureja cuneifolia is thought to exhibit strong biological activity due to the phenolic acid and flavonoid compounds in the methanol extracts.

As far as we know, data on the in vitro anti-urease, cytotoxic and in vivo anti-inflammatory effects of $S$. cuneifolia have not been published. In this study, unlike other literature information, the anti-urease, cytotoxic and anti-inflammatory effects of different extracts of the plant were investigated for the first time.

\section{Conclusions}

In the current study, it was found that the fraction methanol extract showed stronger ABTS and FRAP activity than other extracts as well as it contained a higher amount of phenolic contents. A linear relationship was determined between the amount of phenolic contents contained in this extract and antioxidant activity. The activity results of the extracts on the enzymes (urease, acetylcholinesterase) showed that the fraction methanol extract had the strongest anti-urease and anticholinesterase activity. XTT results showed that the fraction methanol extract had the most cytotoxic activity on MCF-7 cell lines, but it was a promising result that it was not cytotoxic on the L-929 cell line. It was determined that both extracts from the plant's aerial parts showed significant in vivo anti-inflammatory activity. The fact that methanol extracts have significant biological activity suggests that these may be used as a natural source in the future. Therefore, it is thought that more comprehensive studies are needed for these extracts.

\section{Acknowledgements}

This research received no specific grant from any funding agency in the public, commercial, or not-forprofit sectors.

\section{Conflict of Interests}

The authors declare that there are no conflicts of interest related to this article.

\section{References}

Amanlou M, Dadkhah F, Salehnia A, Farsam H, Dehpour AR (2005). An anti-inflammatory and anti- nociceptive effects of hydroalcoholic extract of Satureja khuzistanica Jamzad extract. Journal of Pharmacy and Pharmaceutical Sciences 8(1):102-106. https://pubmed.ncbi.nlm.nih.gov/15946603/

Ayoub Z, Mehta A, Mishra SK, Ahirwal L (2017). Medicinal plants as natural antioxidants: A review. Journal of Botanical Society 48:1-9. https://www.researchgate.net/publication/327573857

Benzie IF, Strain JJ (1996). The ferric reducing ability of plasma (FRAP) as a measure of "antioxidant power": the FRAP assay. Analytical Biochemistry 239(1):70-76. https://doi.org/10.1006/abio.1996.0292

Bezi N, SkoIbu M, Jaunk V (2005). Phytochemical composition and antimicrobial activity of Satureja montana L. and Satureja cuneifolia Ten. essential oils. Acta Botanica Croatica 64(2):313-322. https://hrcak.srce.hr/3352

Butterfield DA, Halliwell B (2019). Oxidative stress, dysfunctional glucose metabolism and Alzheimer disease. Nature Reviews Neuroscience 20(3):148-160. https://dx.doi.org/10.1038/s41583-019-0132-6 
Ellman GL, Courtney KD, Andres Jr V, Featherstone RM (1961). A new and rapid colorimetric determination of acetylcholinesterase activity. Biochemical Pharmacology 7(2):88-90. https://doi.org/10.1016/00062952(61)90145-9

Fang YZ, Yang S, Wu G (2002). Free radicals, antioxidants and nutrition. Nutrition 18(10):872-879. https://doi.org/10.1016/S0899-9007(02)00916-4

García-Rellána D, Verdeguer M, Salamone A, Amparo Blázquez M, Boira H (2016). Chemical composition, herbicidal and antifungal activity of Satureja cuneifolia essential oils from Spain. Natural Product Communications 11(6):841-844. https://pubmed.ncbi.nlm.nih.gov/27534131/

Hajhashemi V, Zolfaghari B, Yousefi A (2012). Antinociceptive and anti-inflammatory activities of Satureja hortensis seed essential oil, hydroalcoholic and polyphenolic extracts in animal models. Medical Principles and Practice 21(2):178-182. https://doi.org/10.1159/000333555

Hanif M, Shoaib K, Saleem M, Rama NH, Zaib S, Iqbal J (2012). Synthesis, urease inhibition, antioxidant, antibacterial, and molecular docking studies of 1,3,4-oxadiazole derivatives. International Scholarly Research Network Pharmacology 2012:1-9. https://doi.org/10.5402/2012/928901

Henstridge CM, Hyman BT, Spires-Jones TL (2019). Beyond the neuron-cellular interactions early in Alzheimer disease pathogenesis. Nature Reviews Neuroscience 20(2):94-108. https://doi.org/10.1038/s41583-018-0113-1

Holleczek B, Schöttker B, Brenner H (2020). Helicobacter pylori infection, chronic atrophic gastritis and risk of stomach and oesophagus cancer: results from the prospective population-based esther cohort study. International Journal of Cancer 146:2773-2783. https://doi.org/10.1002/ijc.32610

Jafari F, Ghavidel F, Zarshenas MM (2016). A Critical overview on the pharmacological and clinical aspects of popular Satureja species. Journal of Acupuncture and Meridian Studies 9(3):118-127. https://doi.org/10.1016/j.jams.2016.04.003

Kindl M, Blažeković, B, Bucar F, Vladimir-Knežević S (2015). Antioxidant and anticholinesterase potential of six Thymus Species. Evidence-Based Complementary and Alternative Medicine 2015:1-10. http://dx.doi.org/10.1155/2015/403950

Long JM, Holtzman DM (2019). Alzheimer disease: an update on pathobiology and treatment strategies. Cell $179(2): 312-339$. https://doi.org/10.1016/j.cell.2019.09.001

Mimica-Dukić N, Simin N, Orčić D, Lesjak M, Knežević P, Aleksić V, Buzas K (2018). Therapeutic efficiency of essential oils against Helicobacter pylori infections. Facta Universitatis, Series Physics, Chemistry and Technology 16(1):2932. http://casopisi.junis.ni.ac.rs/index.php/FUPhysChemTech/

Mogana R, Adhikari A, Debnath S, Hazra S, Hazra B, Teng-Jin K, Wiart C (2014). The antiacetylcholinesterase and antileishmanial activities of Canarium patentinervium Miq., BioMed Research International 2014:1-7. http://dx.doi.org/10.1155/2014/903529

Oke F, Aslim B, Ozturk S, Altundag S (2009). Essential oil composition, antimicrobial and antioxidant activities of Satureja cuneifolia Ten. Food Chemistry 112(4):874-879. https://doi.org/10.1016/j.foodchem.2008.06.061

Ozsoy N, Can A, Yanardağ R, Akev N (2008). Antioxidant activity of Smilax excels L. leaf extracts. Food Chemistry 110(3):571-583. https://doi.org/10.1016/j.foodchem.2008.02.037

Ramos-Tovar E, Muriel P (2020). Free Radicals, Antioxidants, nuclear factor-e2-related factor-2 and liver damage. Journal of Applied Toxicology 40(1):151-168 https://doi.org/10.1002/jat.3880

Re R, Pellegrini N, Proteggente A, Pannala A, Yang M, Rice-Evans C (1999). Antioxidant activity applying an improved abts radical cation decolorization assay. Free Radical Biology and Medicine 26(9-10):1231-1237. https://doi.org/10.1016/S0891-5849(98)00315-3

Sadeghi I, Yousefzadi M, Behmanesh M, Sharifi M, Moradi A (2013). In vitro cytotoxic and antimicrobial activity of essential oil from Satureja intermedia. Iranian Red Crescent Medical Journal 15(1):70-74. https://pubmed.ncbi.nlm.nih.gov/23487431/

Taskin T, Çam ME, Taşkın D, Rayaman E (2019). In vitro and In vivo biological activities and phenolic characterization of Thymus praecox subsp. skorpilii var. skorpilii. Journal of Food Measurement and Characterization 13:536-544. https://doi.org/10.1007/s11694-018-9967-1 
Taslimi P, Kokksal E, Goren AC, Bursal E, Aras A, Kılıc O, Alwasel S, Gulçin I (2020). Anti-Alzheimer, antidiabetic and antioxidant potential of Satureja cuneifolia and analysis of its phenolic contents by LC-MS/MS. Arabian Journal of Chemistry 13(3):4528-4537. https://doi.org/10.1016/j.arabjc.2019.10.002

Taşkın D, Taşkın T, Rayaman E (2018). Phenolic composition and biological properties of Acbillea nobilis L. subsp. neilreichii (Kerner) Formanek. Industrial Crops and Products 111:555-562 https://doi.org/10.1016/j.indcrop.2017.11.022

Tepe B, Cilkiz M (2015). A pharmacological and phytochemical overview on Satureja. Pharmaceutical Biology 54(3):375412. https://doi.org/10.3109/13880209.2015.1043560

Vazquez E, Navarro M, Salazar Y, Crespo G, Bruges G, Osorio C, ... Lopez M (2015). Systemic changes following carrageenan-induced paw inflammation in rats. Inflammation Research 64:333-342. https://doi.org/10.1007/s00011-015-0814-0.

Wolf NB, Küchler S, Radowski MR, Blaschke T, Kramer KD, Weindi G (2009). Influences of opioids and nanoparticles on in vitro wound healing models. European Journal of Pharmaceutics and Biopharmaceutics 73(1):34-42. https://doi.org/10.1016/j.ejpb.2009.03.009

Yousefzadi M, Riahi-Madvar A, Hadian J, Rezaee F, Rafiee R (2012). In vitro cytotoxic and antimicrobial activity of essential oil from Satureja sahendica. Toxicological and Environmental Chemistry 94(9):1735-1745. https://doi.org/10.1080/02772248.2012.728606
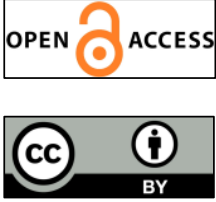

The journal offers free, immediate, and unrestricted access to peer-reviewed research and scholarly work. Users are allowed to read, download, copy, distribute, print, search, or link to the full texts of the articles, or use them for any other lawful purpose, without asking prior permission from the publisher or the author.

License - Articles published in Notulae Scientia Biologicae are Open-Access, distributed under the terms and conditions of the Creative Commons Attribution (CC BY 4.0) License.

(C) Articles by the authors; SHST, Cluj-Napoca, Romania. The journal allows the author(s) to hold the copyright/to retain publishing rights without restriction. 